\section{Naurun filosofiaa}

Hietalahti, Jarno (2018). Huumorin ja naurun filosofia. Gaudeamus. 315 sivua.

ERASMUS ROTTERDAMILAISEN (1466-1536) mukaan nauru on luonnonvoima, joka murtaa järjen vankimmatkin rakennelmat. Bertrand Russell (1872-1970) totesi, että huumori tekee tutun oudoksi ja oudon tutuksi. Ludwig Wittgensteinin (1889-1951) kerrotaan sanoneen, että kokonainen filosofinen teos olisi syytä kirjoittaa vitsin muotoon.

Entä voiko tekoäly luoda huumoria? Kyllä vitsejä varmaan syntyisi, mutta seuraava kysymys on, oppisiko tekoäly nauramaan myös omille algoritmeilleen.

Huumorin ja naurun filosofian kirjoittaja, tutkijatohtori Jarno Hietalahti kysyy, mitä tapahtuu naurun jälkeen. Auttaako huumori näkemään asioita uusin silmin vai ei? Terveystutkijat kehottavat nauramaan vaikka tyhjälle aina kun mahdollista, mutta sen sijaan olisi pureuduttava huumorin ytimiin ja katsottava, millainen ihmiskuva taustalta paljastuu.

\section{MITEN HUUMORI ON?}

Teos keskittyy paitsi siihen, mitä huumori on myös miten se on meille, miten huumori ilmenee ja miten siihen suhtaudumme. Sijansa saavat huumorin tavallisimmat teoriat, filosofien suhtautuminen naurun ja huumorin ilmiöihin eri aikakausina, huumori utopian ja pyhän osana, huumori elämänasenteena, huumorin etiikka sekä huumori yhteiskunnallisen ilmiönä.

Huumorin tai komiikan genret eivät kirjassa saa suurta huomiota, mutta huumorin ja naurun keskinäisen suhteen monitahoisuus tulee hyvin esiin. Painavimman sanottavansa tekijä säästäa huumorin kritiikkiin ja kriittiseen huumoriin. Huumorin etiikan käsittely jää vähemmän jäsentyneeksi, mutta jonkinlaisen kuvan seuraus-, velvollisuus- ja hyve-etikasta huumorin yhteydessä lukija saa. Loppuluvussa tekijä pohtii humaanin huumorin mahdollisuutta.

Lukujen lopussa on hiema päälle liimatun tuntuisesti huumoriammattilaisten mietteitä. Heidä näkökulmansa on useimmiten sama kuin Cicerolla (106-43 eaa.) sen pohdinta, millainen huumo "tehoaa" kuulijoihin ja katsojiin.

\section{HUUMORIN TEORIAA}

Antiikin filosofit eivät hyvästä elämästä puhuessaan tehneet ero yksilön ja yhteiskunnan välilla. Platonin (427-347 eaa.) mielestä nauru suuntaa huomion pois olennaisista asioista, kun taas Aristoteleelle (384-322 eaa.) huumorintaju on sosiaalinen hyve, jok kohtuullisesti harjoitettuna edistää sosiaalista elämää. Kun yhteisö eli valtio voi hyvin, yksilö voi hyvin ja päinvastoin.

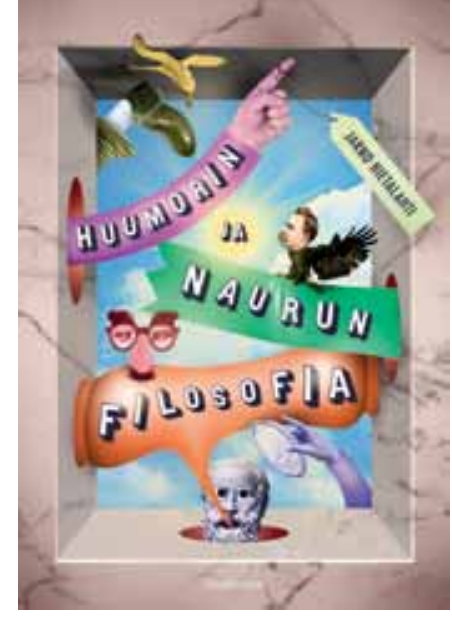

Senkin uhalla, että liiallinen huumorin analysointi voi tappaa kohteensa, lukija vakuuttuu siitä, että on hyödyllistä tutustua tavallisimpiin huumorin teorioihin, kuten ylemmyys-, huojennus- ja yhteensopimattomuusteorioihin. Englantilaisfilosofi Thomas Hobbesin mukaan (1588-1679) nauru on ilmausta äkillisestä ylemmyydentunteesta, kun ihminen havaitsee toisen itseään huonommaksi. Nauru pohjautuu toisen epäonnistumiseen ja naurajan ylivoimaiseen tietoon siitä, miten asioiden tulisi olla. Tragedia ja komedia kumpuavat samasta lähteestä, epäilee Sokrates Platonin Pidotdialogissa.

Huojennusteorian mukaan huumori toimii varaventtiilinä, ja naurussa vapautuu suuri määrä energiaa, mihin perustunee myös käsitys naurun parantavasta voimasta ja elonpäivien pidennyksestä. Tunnetuin huojennusteorian puolestapuhuja oli Sigmund Freud (1856-1939), joka samalla vastusti huumorin ylemmyysteoria.
Nauraja tietää, ettei olisi itse selvinnyt paremmin kuin epäonnistuja, jolle hän nauraa, mutta saattaa olla samalla huojentunut, ettei itselle käynyt tällä kertaa samoin

Missä on ristiriitaa, löytyy myös koomisuutta, ajattelee tanskalaisfosofi Søren Kierkegaard (1813

1855). Yhteensopimattomuus- e inkongruenssiteoria lähtee nykyisin varsin yleisesti hyväksytystä ajatuksesta, että huumorin ytimessä on ristiriita. Huumori kutsuta tai se ilmaantuu kutsumatta paikae, kun odotusten ja tapahtumie väliin ilmaantuu särö.

\section{HÄPEÄ JA KARNEVAALI}

Ranskalaisfilosofi Henri Bergsonill (1859-1941) oli naurusta varsin iluusioton käsitys: naurun tarkoitus on aiheuttaa kohteelleen tuskallinen kokemus. Nauru aiheuttaa häpeää, kun se suuntautuu kohteensa noloihin ominaisuuksiin.

Hietalahti kiinnittää huomiot paradoksiin: pyrimme kaikin keinoin välttämään naurunalaiseks ja häväistyksi joutumista, mutta samalla odotetaan kykyä naura itselleen. Huumori käy jatkuva taistelua häpeää vastaan ja pyrk yhteiskunnalliseen tilaan, jossa itse kunkin nolot piirteet uskaltaa tuoda esiin ilman seurauksia.

Hietalahti kysyy seuraavaks millainen olisi naurun läpäisemä maailma. Aihetta on käsitellyt venäläinen kirjallisuustutkija Mihail Bahtin (1895-1975) keskiaikaisen karnevaalinaurun tutkimuksissaan. $\mathrm{O}$ harmillista, että Hietalahden muuten ansiokkaassa teoksessa Bahtin jää vaille arvoistaan käsittelyä.
Naurulla ja huumorilla on aina ollut Erich Frommin mukaan emm yhteiskunnallinen ja kriittinen ulot- ole vapautuneet sisäisesti, vaik tuvuus. Vallanpitäjät ovat monesti ka monia kahleita on onnistuttu vapisseet naurun edessä, mutta he historian saatossa katkaisemaan. ovat myös osanneet käyttää huumo- Ajattelemme ja toistamme samoria valtansa lujittamiseen. Umberto ja asioita kuin muutkin emmekä con (1932-2016) romaanissa nouse omaperäisen ajattelun taRuusun nimi etsitään 1300-luvulla solle. Huumorista voi tulla valtaluostarin kirjastosta Aristoteleen taistelun ja väkivallan väline. KuRunousopin kadonnutta, komediaa kaan ei saa estää meitä esittämäsäsittelevää kakkososaa. Kirja oli tä ajatuksiamme, mutta ne eivät vallanpitäjille niin vaarallinen, että useinkaan ole omiamme. Poliittikirjaston piti tuhoutua.

Monet koomikot ruotivat yh- pautta vain silloin, kun se voi tukea teiskunnallisia epäkohtia ja ir- kehittymistä.

vailevat vallanpitäjille. Kriittinen Myös hymy on usein pakonhuumori ei jää tähän, vaan tuo omaista ja laskelmoivaa Uranmeidät ihmetyksen tilaan, pureu- rakennusoppaissa kehotetaan tuu yhteiskunnan perustuksiin ja hymyilemään kroonisesti, mutta samalla kyseenalaistaa vallitsevan ilosta, ystävällisyydestä ja tyytyväihuumorin kulttuurin, myös hu- syydestä irronnut hymy"lävähtä moristin omat käsitykset. naamalle kuin kuola Pavlovin koiFrankfurtin koulukunnan rien suupieleen.

Theodor Adorno (1903-1969), Hietalahden mukaan olennaista Erich Fromm (1900-1980) ja huumorissa ei ole niinkään, mitä se Max Horkheimer (1895-1973) on vaan, miten aihetta käsitellään. kritisoivat huumoria latistavan ja Monet koomikot korostavat, että laskelmoivan viihdeteollisuuden kaikesta on voitava vitsailla, mutosana. Tyhjänpäiväisellä viihteel- ta se ei tarkoita, että mistä tahansa lä itsensä turruttaminen voi olla pitäisi vitsailla kaiken aikaa. Kirvapautta jostakin, muttei vapautta joittaja hahmottelee humanistista johonkin. Huumori ja nauru ovat huumoria, jossa vitsin sisältöä olenarvokkaita itsetoteutuksen aluei- naisempaa on, miten sisältöä käyteta, mutta kapitalismin logiikalle tään ja millaista suhdetta huumori alistettu kulttuuriteollisuus palve- rakentaa muihin. Sananvapaus ei lee ideologista herruutta yksilön tarkoita rajatonta oikeutta hyökätä vapauden kustannuksella. Yh- minkä tahansa tai kenen tahansa teiskunta kauppaa yksilöllisyyttä, kimppuun. mutta korulauseiden takaa paljas tuu loputon toisto. Kun hierarkiat nurin kääntävän narrin pu ei enää helise, viihteessä helise enää kapitalismin rahakukkaro. 